\title{
Originals
}

\section{The Crystal Structures of Three Non-Pancreatic Human Insulins*}

\author{
S. A. Chawdhury ${ }^{1}$, E. J. Dodson", G. G. Dodson ${ }^{1}$, C. D. Reynolds ${ }^{1}$, S. P. Tolley ${ }^{1}$, T. L. Blundell ${ }^{2}$, A. Cleasby ${ }^{2}$, \\ J.E. Pitts' ${ }^{2}$ I.J. Tickle ${ }^{2}$ and S. P. Wood ${ }^{2}$ \\ ${ }^{1}$ Department of Chemistry, University of York, and ${ }^{2}$ Laboratory of Molecular Biology, Department of Crystallography, Birkbeck College, \\ University of London, London, UK
}

\begin{abstract}
Summary. X-ray studies on semi-synthetic human insulin have shown that it crystallizes in the rhombohedral space group R3 and is nearly isomorphous with $2 \mathrm{Zn}$ pig insulin. Precession photographs of crystals of human and pig insulins show observable changes in the intensity patterns. Crystallographic analysis and refinement of semi-synthetic human insulin at $1.9 \AA$ resolution have shown that its molecular structure is very like that of pig insulin except at the $C$-terminus of the $B$ chain where the change in sequence occurs. We also report the results of a high resolution crystallographic study of
\end{abstract}

human insulins from different origins. The X-ray diffraction patterns of three non-pancreatic human insulins are indistinguishable from each other and from pancreatic human insulin. Refinement of the structures of the non-pancreatic human insulins has shown that they are identical within the limits of experimental error.

Key words: Non-pancreatic human insulins, pancreatic human insulin, crystal structure.
Insulin with the exact chemical structure of the human hormone has been made available recently for the treatment of diabetes. The human insulins were manufactured by quite different methods (semi-synthetically, by chemical modification of pig insulin [1], and biosynthetically, by recombinant DNA technology $[12,13]$. It has been demonstrated that the human insulins produced by these very different preparative pathways are analytically and biochemically indistinguishable [10]. The production of human insulin by recombinant DNA techniques is therefore established and will in the future have an immense impact on the patterns of insulin manufacture.

Human insulin differs from the pig insulin sequence only at the C-terminal $\mathrm{B}$ chain residue which in pig insulin is alanine and in human insulin threonine. We report here the $2 \mathrm{Zn}$ insulin crystal structure of human insulin prepared by semi-synthetic methods (Novo) [1] and compare it with the accurately known pig $2 \mathrm{Zn}$ insulin crystal structure [3]. A comparison between human $2 \mathrm{Zn}$ insulin crystals from pancreatic and non-pancreatic sources is given also in this study.

\footnotetext{
* The determination of the human (semi-synthetic) $2 \mathrm{Zn}$ insulin structure was carried out at the University of York. The part of the paper in which the human $2 \mathrm{Zn}$ insulin crystal structures from different origins are compared was carried out at Birkbeck College (London) and the University of York.
}

Comparison between the human and pig $2 \mathrm{Zn}$ insulin crystal structures reveals that the different sequence at B 30 has altered the hormone's conformation only at B 29 and B 30. These small but distinct changes, however, affect the interactions between the hexamers in the crystal.

It was thought desirable to investigate the $2 \mathrm{Zn}$ insulin crystal structures of the differently prepared human insulins. Crystal formation requires not only the proper folding and assembly of the constituent molecules but also that they make, with exact repetition, very specific and delicate contacts. Thus the structural identity of crystals is a sensitive test of the molecule's structural integrity. The technique also demonstrates whether or not the crystal packing has been perturbed in specimens of different origin, thus helping to ensure that the different crystals have identical physical properties. The study also provided a useful opportunity to assess protein refinement procedures [14].

\section{Materials and Methods}

Rhombohedral 2-zinc insulin crystals were grown using the batch crystallization method of Schlichtkrull [2] for human insulin samples prepared by enzymatic modification of pig insulin (Novo), by bacterial production of the separate $A$ and $B$ chains from their synthetic genes (Lilly), by conversion of proinsulin produced from micro- 
Table 1. Crystal data for human and pig $2 \mathrm{Zn}$ insulin

\begin{tabular}{|c|c|c|c|c|c|c|c|c|c|}
\hline Insulin & $\begin{array}{l}\text { Space } \\
\text { group }\end{array}$ & \multicolumn{4}{|c|}{ Cell parameters } & $\begin{array}{l}\text { Resolution } \\
(\AA)\end{array}$ & $\begin{array}{l}\text { No. of } \\
\text { reflec- } \\
\text { tions }\end{array}$ & $\begin{array}{l}\mathrm{R}^{\mathrm{a}} \\
(\%)\end{array}$ & $\begin{array}{l}\text { Estimated } \\
\text { standard } \\
\text { deviation } \\
\text { (̊) }\end{array}$ \\
\hline $\begin{array}{l}\text { Semi-synthetic } \\
\text { human insulin }\end{array}$ & R3 & 82.85 & 82.85 & 34.0 & 120 & $10.0-1.9$ & 6283 & 17.3 & $0.1-0.5$ \\
\hline Pig insulin & $\mathrm{R} 3$ & 82.50 & 82.50 & 34.0 & 120 & $10.0-1.5$ & 13700 & 17.9 & $0.05-0.3$ \\
\hline
\end{tabular}

a $\mathbf{R}=\left(\Sigma\left|\mathrm{F}_{\mathrm{o}}\right|-\left|\mathrm{F}_{\mathrm{c}}\right|\right) / \Sigma\left|\mathrm{F}_{\mathrm{c}}\right|$, where $\left|\mathrm{F}_{\mathrm{o}}\right|,\left|\mathrm{F}_{\mathrm{c}}\right|$ are the relevant observed and calculated structure amplitudes

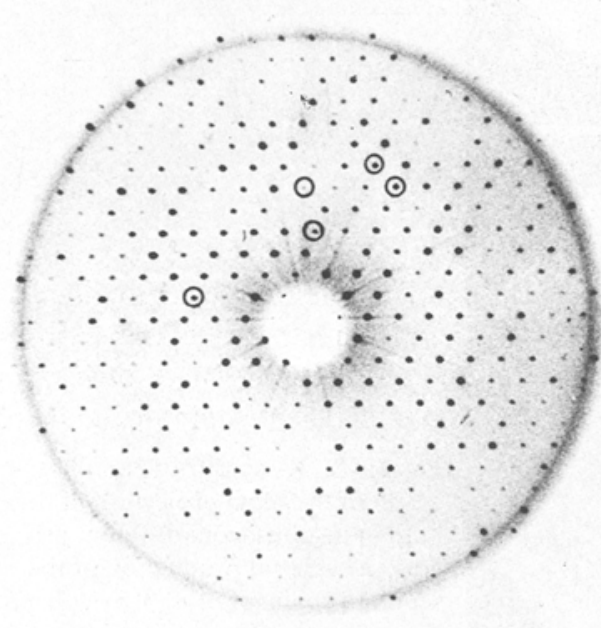

HUMAN 2 Zn INSULIN (NOVO) Okl $u=18^{\circ}$ SEMISYNTHESIS FROM PIG INSULIN

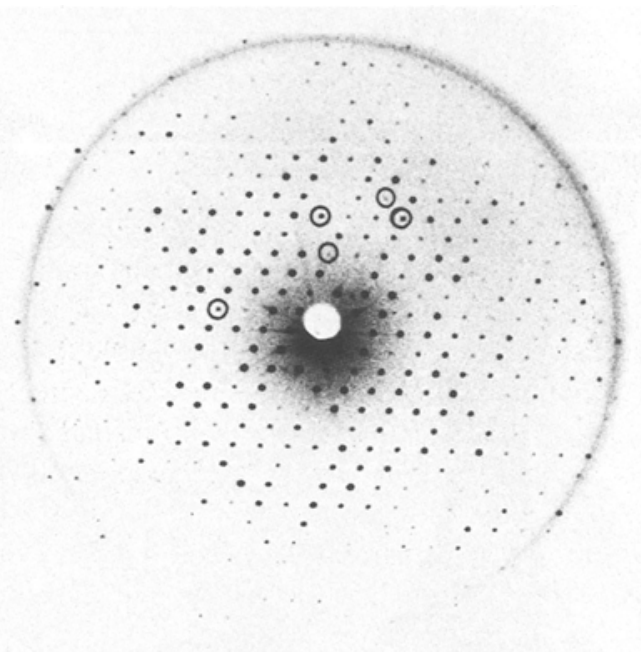

PIG 2 Zn INSULIN Okl $\mathrm{u}=21^{2}$
Fig. 1. Comparison of X-ray diffraction patterns of semi-synthetic human insulin (left) and $2 \mathrm{Zn}$ pig insulin (right). Equivalent reflections showing distinct intensity changes are circled. (Okl projection) organisms (Lilly), and from the human pancreas. Insulin crystals were mounted in sealed capillary tubes containing a few drops of mother liquor.

Three-dimensional X-ray diffraction data to $1.9 \AA$ A resolution were collected using $\mathrm{CuK} \alpha$ radiation on a four-circle diffractometer (Hilger \& Watts, London, UK) controlled by a PDP-11 computer (Digital, Maynard, USA). The data were collected with an $\omega$-scan technique with $30-40$ steps of $0.03^{\circ}$ and step times of $1-4 \mathrm{~s}$. Radiation damage and crystal alignment were monitored by measuring the intensities of three standard reflections after every 100 reflections. Intensities were corrected for background, Lorentz and polarization effects and semi-empirical absorption corrections were applied [4].

$\mathrm{X}$-ray diffraction patterns of the hkiO projections of four types of human insulin were recorded photographically using a precession camera (Nonius, Delft, The Netherlands). X-ray reflections to $1.9 \AA$ resolution from the other non-pancreatic human insulin crystals were measured automatically on a computer-controlled four-circle Hilger Watts diffractometer using $\mathrm{CuK} \alpha$ radiation. The reflections were corrected for background, Lorentz and polarization effects, and for absorption using the semi-empirical method [4].

\section{Results}

Crystal data for both human (Novo) and pig $2 \mathrm{Zn}$ insulin are given in Table 1 . There are distinct changes in the intensity patterns observed between human (Novo) and pig insulins (Fig.1). X-ray diffraction patterns of the hkiO projections of four types of human insulin were found to be indistinguishable (Fig. 2).
The difference Fourier technique has been widely applied in the study of protein structures [11], since it provides a sensitive monitor of conformational changes and is useful for detecting errors in atomic positions.

An initial difference Fourier map was calculated for the Novo human insulin with coefficients $\left(\left|F_{\text {human }}\right|-\right.$ $\left.\left|F_{\text {calc }}\right|\right)$ and phases $\alpha_{\text {calc }}$, where $\left|F_{\text {human }}\right|$ is the observed structure amplitude for human insulin and $\left|F_{\text {calc }}\right|$ and $\alpha_{\text {calc }}$ are the calculated structure amplitudes and phases derived from the pig $2 \mathrm{Zn}$ insulin crystal cell. The residues B 28-B 30 were excluded from the calculation of $\left|\mathrm{F}_{\text {calc }}\right|$ and the phase $\alpha_{\text {calc }}$, since significant differences in their atomic positions arising from the sequence change at B30 were possible. This map revealed the positions of the threonine atoms at B30 and indicated some distinct shifts in the B 30 carboxyl groups. Changes in the water structure in the region of B28-B 30 were observed also.

The new atomic coordinates for the B 30 threonine side chain and C-terminal carboxyl group for both molecules in the asymmetric unit, together with the coordinates of the rest of the molecule and solvent (obtained by placing the pig $2 \mathrm{Zn}$ insulin coordinates in the human $2 \mathrm{Zn}$ insulin cell) were then refined crystallographically using the fast Fourier least-squares method $[5,6]$. 

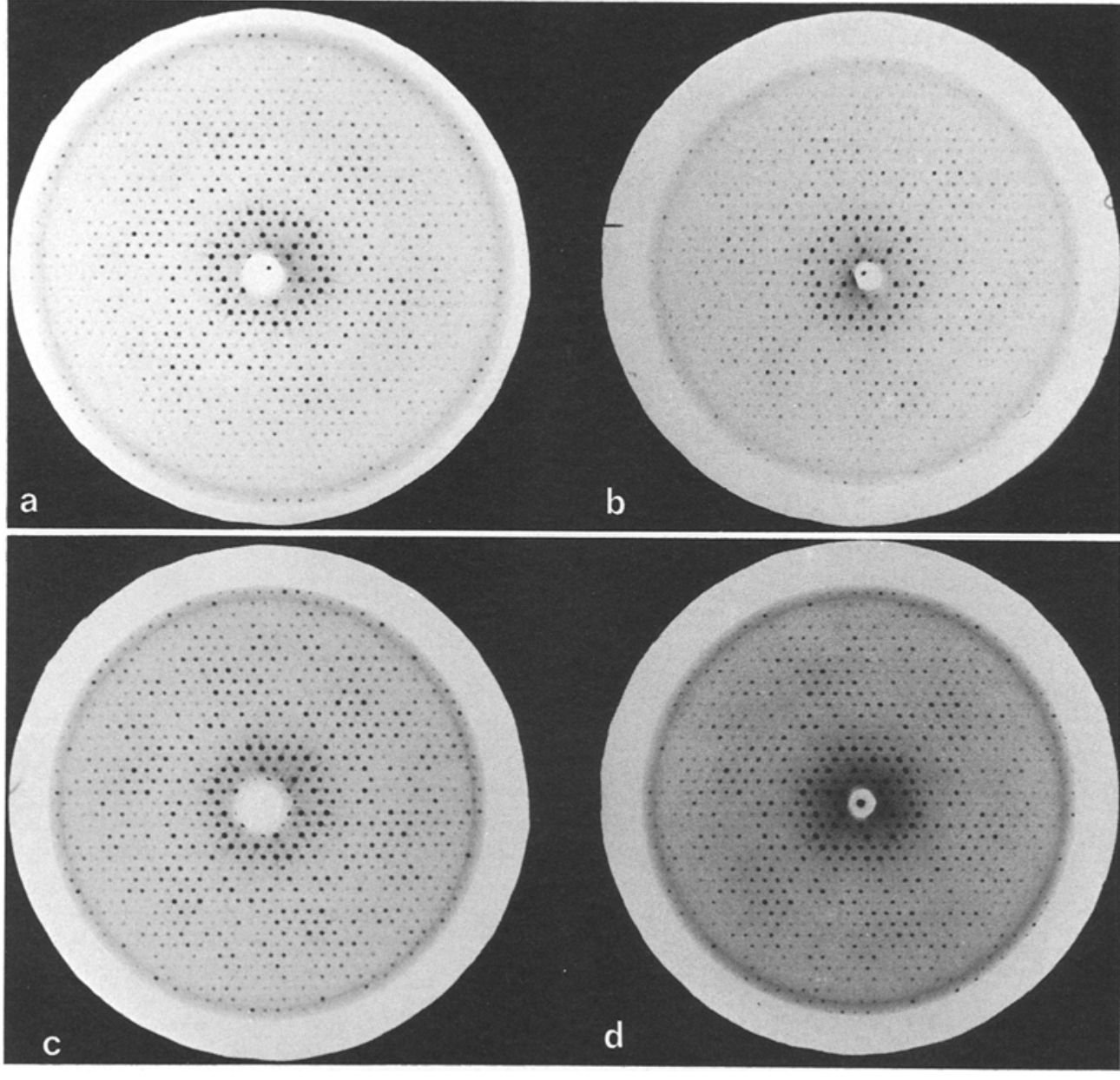

Fig. 2a-d. X-ray diffraction photograph of the hkiO projection of four human insulins from different origins. a bacterial production of the separate chains (Lilly); b by conversion of proinsulin produced from bacteria (Lilly); c semi-synthetic (Novo); and drom the human pancreas

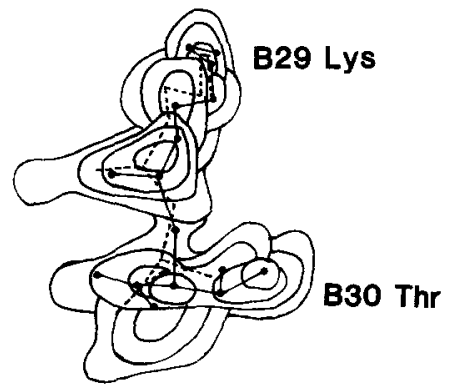

Molecule I

(a)

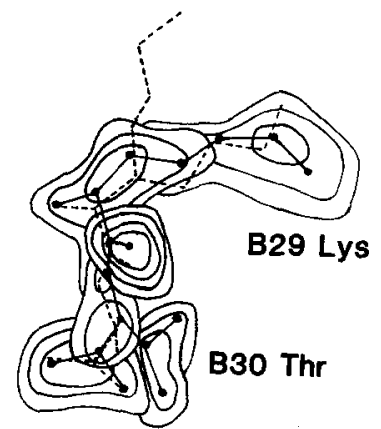

Molecule II

(b)

Fig. 3. Difference Fourier maps in the region of residues B29-B30 for (a) molecule I and (b) molecule II of semi-synthetic human insulin (full lines). For comparison the pig insulin atomic positions are shown (broken lines)

After convergence of the least squares refinement, a further difference Fourier map was calculated using as coefficients $\left(\left|\mathrm{F}_{\text {human }}\right|-\left|\mathrm{F}_{\mathrm{c}}\right|\right)$ and, as phases $\alpha_{c}$, where $\left|\mathrm{F}_{\mathrm{c}}\right|$ and $\alpha_{\mathrm{c}}$ are the calculated structure amplitudes and phases determined from the refined human insulin

coordinates, excluding the residues B28-B30 and some of the surrounding solvent molecules. Improved atomic coordinates for some atoms were obtained from this difference map and further least-squares refinement cycles were carried out. Figure 3 illustrates the final difference Fourier map at the C-terminus of the B chain for both molecules. The standard deviations in the atomic positions ranged from $0.1 \AA$ for well-defined atoms to $0.5 \AA$ for poorly defined atoms. The root mean square difference between the atomic positions of human (Novo) and pig insulins after optimization on equivalent atoms are (a) $0.15 \AA$ for the main chain atoms only and (b) $0.21 \AA$ for all atoms (excluding residues B29-B30). Thus the two insulins are structurally identical within the limits of error for all atoms except B29 and B 30 (Figure 4).

Difference density maps for the other two non-pancreatic human insulins were calculated with coefficient $\left(\left|F_{\text {human }}\right|-\mid F_{\text {calc }}\right)$ where $\left|F_{\text {human }}\right|$ is the observed structure amplitude for the particular human insulin and $\left|F_{\text {calc }}\right|$ is the calculated structure amplitude derived from the pig $2 \mathrm{Zn}$ insulin unit cell. In the calculation of $\left|\mathrm{F}_{\text {calc }}\right|$ and the corresponding phase $\alpha_{\text {calc }}$, the residues B 28-B 30 were excluded since differences in their atomic positions were expected. These maps clearly showed the posi- 


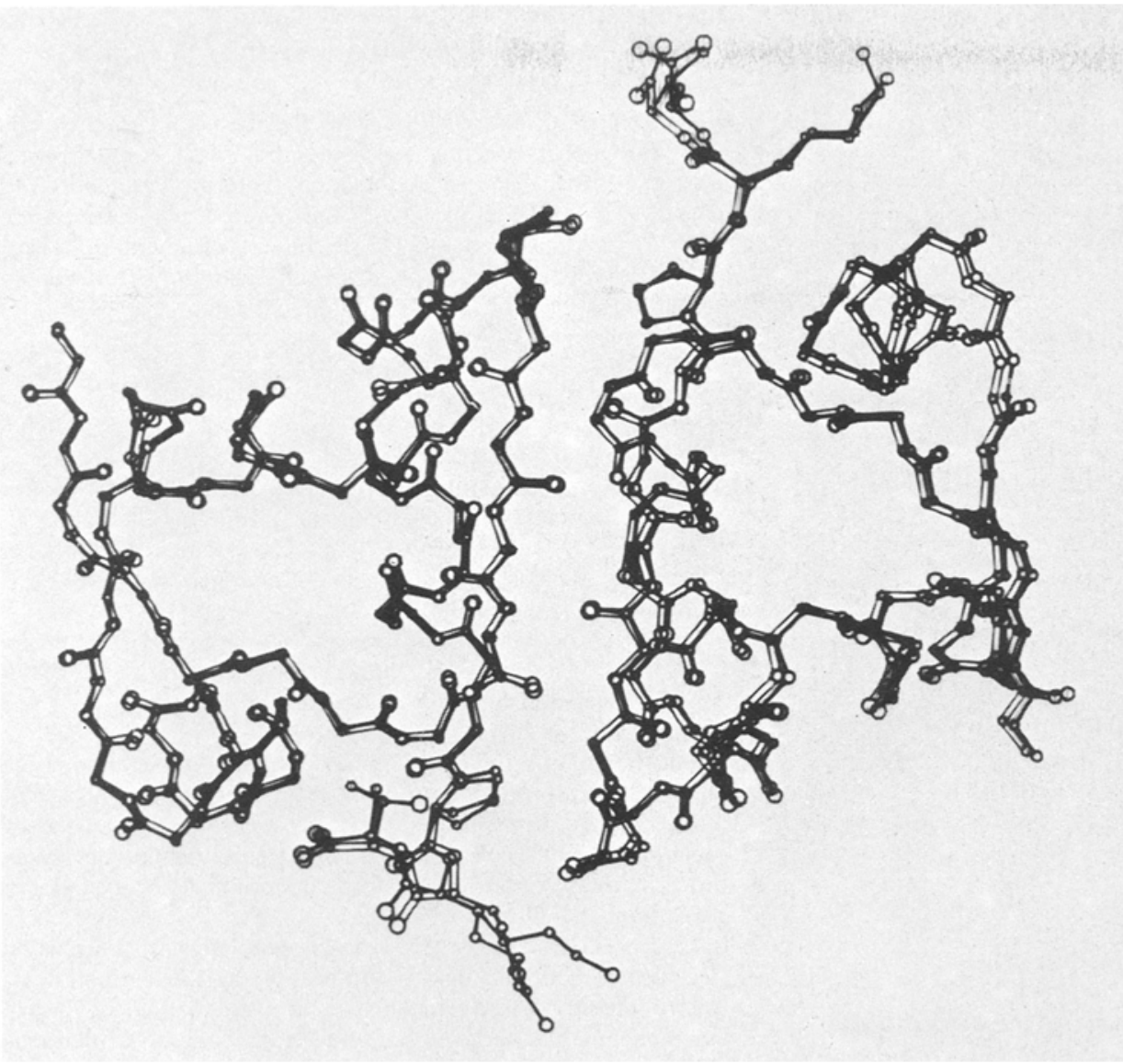

Fig.4. A figure of human insulin (open lin overlapped onto pig insulin (full lines) for 1 molcules I and II viewed down the local twofold axis

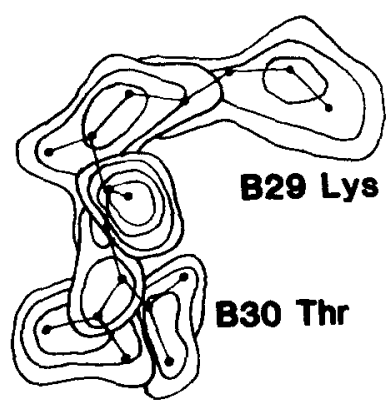

(a)

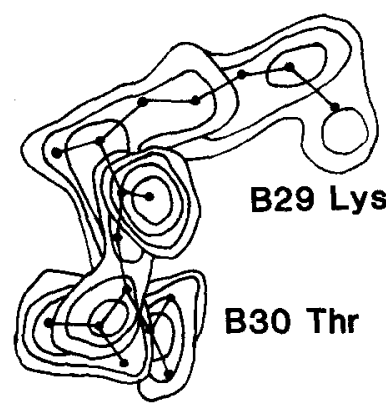

(b)

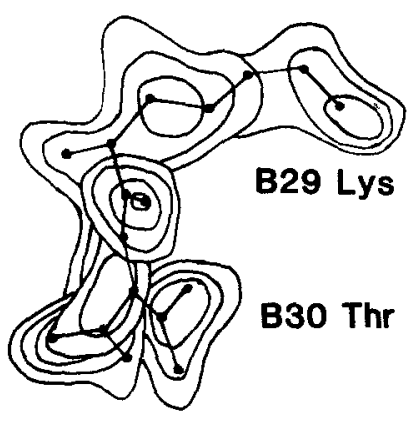

(c)
Fig.5a-c. Difference electron density for B29 lysine and B 30 threonine, molecule II, for a semi-synthetic (Novo), b biosynthetic (from separate chains, Lilly), c biosynthetic (from proinsulin, Lilly) human insulin tions of the B30 threonine side chain, as well as similar shifts in the atoms of B 30 for each of the independent molecules in the asymmetric unit.

Table 2. Refinement results

\begin{tabular}{lllll}
\hline $\begin{array}{l}\text { Human insulin } \\
\text { source }\end{array}$ & $\begin{array}{l}\text { Resolution } \\
(\AA)\end{array}$ & $\begin{array}{l}\text { No. of re- } \\
\text { flections }\end{array}$ & $\begin{array}{l}\mathrm{R}^{\mathrm{a}} \\
(\%)\end{array}$ & $\begin{array}{l}\text { Estimated SD } \\
(\AA)\end{array}$ \\
\hline $\begin{array}{l}\text { Novo } \\
\begin{array}{l}\text { Lilly (from } \\
\quad \text { A + B chains) }\end{array}\end{array}$ & $10.0-1.9$ & 6283 & 17.3 & $0.10-0.5$ \\
$\begin{array}{l}\text { Lilly (from } \\
\text { proinsulin) }\end{array}$ & $10.0-1.9$ & 6547 & 18.5 & $0.10-0.5$ \\
\hline
\end{tabular}

${ }^{a} \mathbf{R}=(\Sigma|\mathrm{Fo}|-|\mathrm{Fc}|) / \Sigma|\mathrm{Fc}|$ (see Table 1)
Fast Fourier least-squares refinement calculations $[5,6]$ were then undertaken for these human insulins, with a starting model derived from the pig $2 \mathrm{Zn}$ insulin coordinates and the new atomic coordinates for the B30 threonine side chain and carboxyl group obtained from the initial difference maps. After convergence, a difference Fourier map was calculated in the region of B 28-B30 and the surrounding solvent. Examples of the difference electron density for B 29 and B 30 for each of the insulins is shown in Figure 5.

Details of the refinement of the three non-pancreatic human $2 \mathrm{Zn}$ insulin crystals are given in Table 2.

The refined coordinates for the three human insulins have been compared and the differences between 
Table 3. Root mean square differences between the atomic positions for the three structures

\begin{tabular}{|c|c|c|c|}
\hline $\begin{array}{l}\text { Structures } \\
\text { compared }\end{array}$ & $\begin{array}{l}\text { Atoms } \\
\text { compared }\end{array}$ & $\begin{array}{l}\text { Root mean } \\
\text { square }(\AA) \\
\text { Molecule I }\end{array}$ & $\begin{array}{l}\text { Root mean } \\
\text { square }(\AA) \\
\text { Molecule II }\end{array}$ \\
\hline Novo & Main chain & 0.16 & 0.14 \\
\hline $\begin{array}{l}\text { Lilly (from } \\
\qquad A+B \text { chains) }\end{array}$ & $\begin{array}{l}\text { Main chain + } \\
\text { side chain }\end{array}$ & 0.24 & 0.20 \\
\hline Novo & Main chain & 0.13 & 0.13 \\
\hline $\begin{array}{l}\text { Lilly (from } \\
\text { proinsulin) }\end{array}$ & $\begin{array}{l}\text { Main chain }+ \\
\text { side chain }\end{array}$ & 0.18 & 0.17 \\
\hline $\begin{array}{l}\text { Lilly (from } \\
\qquad A+B \text { chains) }\end{array}$ & Main chain & 0.18 & 0.16 \\
\hline $\begin{array}{l}\text { Lilly (from } \\
\text { proinsulin) }\end{array}$ & $\begin{array}{l}\text { Main chain }+ \\
\text { side chain }\end{array}$ & 0.23 & 0.22 \\
\hline
\end{tabular}

corresponding atoms calculated (Table 3). Equivalent protein atoms in the three crystal structures did not vary by more than two standard deviations and therefore we conclude that within these limits all three structures are identical.

\section{Discussion}

The differences between the human (Novo) and pig insulin structures are considerably smaller than those found between the two molecules of the $2 \mathrm{Zn}$ pig insulin dimer [3]. The major points of interest are that in human insulin the conformation of the B29 lysine side chain is better defined for both molecules. In molecule I the lysine has a similar conformation to that found in pig insulin whereas in molecule II the lysine has one major conformation which is different from both conformations seen in pig insulin for this side chain. The main chain atoms of B 30 of both molecules have been shifted significantly at the carboxyl groups. Some changes in the solvent structure in the region of $\mathrm{B} 28-\mathrm{B} 30$ are observed also, notably around B29 N and B30 O.

The B29 and B30 residues make a number of interactions in the crystal; the change in sequence at B30 in human insulin has produced some alterations in the intermolecular contacts. The extra $\mathrm{H}$-bonding capacity of the threonine residue at $\mathrm{B} 30$ in human insulin and the altered contacts between the hexamers in the $2 \mathrm{Zn}$ insulin crystals may well have some bearing on the observation that the human $2 \mathrm{Zn}$ insulin crystals attract water more noticeably than the pig $2 \mathrm{Zn}$ insulin crystals in the capillary tubes.

This analysis confirms that although there are considerable differences in the $\mathrm{X}$-ray diffraction patterns of human and pig $2 \mathrm{Zn}$ insulin (Fig. 1) the change at B30 has not significantly affected their 3-dimensional structures. The small but possibly real differences in metabolic behaviour reported with human insulin [7-10] are consistent with slightly enhanced solubility and more rapid absorption. Further biological and clinical studies are needed, however, to determine this.

Acknowledgements. We are grateful for the financial support of the Medical Research Council, the Science and Engineering Research Council, the British Diabetic Association, the Kroc Foundation, Eli Lilly and Novo. We thank Dr. D. Bangham, Dr. R. Chance, Dr. B. Frank, Dr. J. Markussen and Dr. J. Schlichtkrull for useful discussions. We are indebted to the Lilly Research Laboratories and the Novo Research Institute for samples of human insulin.

\section{References}

1. Markussen J, Damgaard U, Jorgensen KH, Snell L (1982) Production of human insulin from porcine insulin. In: Gueriguian JL, Bransone ED, Outschoorn AS (eds) Proceedings of the Joint FDA/USP Workshop on Drug and Reference Standards. USP Convention Inc, Rockville, Maryland, USA, pp 116-126

2. Schlichtkrull J (1958) Insulin crystals. Munksgaard, Copenhagen

3. Dodson EJ, Dodson GG, Hodgkin DC, Reynolds CD (1979) Structural relationships in the $2 \mathrm{Zn}$ insulin hexamer. Can J Biochem $57: 469-479$

4. North ACT, Phillips DC, Mathews FS (1968) A semi-empirical method of absorption correction. Acta Crystallographica A24: 351-359

5. Agarwal RC (1978) A new least-squares refinement technique based on the fast Fourier transform algorithm. Acta Crystallographica A34: 791-809

6. Baker EN, Dodson EJ (1980) Crystallographic refinement of the structure of actinidin at $1.7 \AA$ resolution by fast Fourier leastsquares methods. Acta Crystallographica A36: 559-572

7. Sonnenberg GE, Chantelau E, Sundermann S, Hauff C, Berger M (1982) Human and porcine regular insulins are equally effective in subcutaneous replacement therapy. Diabetes 31:600-602

8. Kemmer FW, Sonnenberg GE, Cuppers HJ, Berger M (1982) Absorption kinetics of semisynthetic human insulin and biosynthetic (recombinant DNA) human insulin. Diabetes Care 5 (Suppl 2): 23-28

9. Clark AJL, Adeniyi-Jones RO, Knight G, Leiper JM, Wiles PG, Jones RH, Keen H, MacCuish AC, Ward JD, Watkins PJ, Cauldwell JM, Glynne A, Scotton JB (1982) Biosynthetic human insulin in the treatment of diabetes. Lancet 2:354-357

10. Home PD, Aberti KGMM (1982) Human insulin. Clin Endocrinol Metab 11: 453-483

11. Blundell TL, Johnson LN (1976) In: Protein crystallography. Academic Press, New York, pp 404-419

12. Goeddel DV, Kleid DG, Bolivar F, Heyneker HL, Yansura DG, Crea R, Hirose T, Kraszewski A, Itakura K, Riggs AD (1979) Expression in E.coli of chemically synthesised genes for human insulin. Proc Natl Acad Sci USA 76: 106-110

13. Chance RE, Kroeff EP, Hoffman JA, Frank BH (1981) Chemical, physical and biological properties of biosynthetic human insulin. Diabetes Care 4: 147-154

14. Machin PA, Campbell JW, Elder M (eds) (1980) Refinement of protein structures. Proceedings of the Daresbury Study Weekend, SERC (Daresbury), Warrington, UK

Received: 16 May 1983

and in revised form: 8 September 1983

Dr. G.G. Dodson

Department of Chemistry

University of York

Heslington

York YO1 5DD, UK 